\title{
GDPs of the USSR and Eastern Europe: Towards an Interwar Comparison*
}

\author{
Mark Harrison** \\ Department of Economics \\ University of Warwick
}

* This paper was published in Europe-Asia Studies 46:2 (1994), pp. 243-259.

** Mail: Department of Economics, University of Warwick, Coventry CV4 7AL. Email: mark.harrison@warwick.ac.uk. I thank Eva Ehrlich (Budapest) for advice and assistance, which included making her data and working papers freely available to me; without this generous sharing of many years' work, the present article could not have been written. I thank Melanie Brown for her prompt and accurate translation from Hungarian, and my colleagues Nick Crafts, Jeff Round and Mark Stewart for helpful advice. This research is supported financially by a grant from the Leverhulme Trust towards research on "Soviet production, employment and the defence burden, 1937 and 1940-1945". I am responsible for remaining errors of fact and interpretation. 


\section{GDPs of the USSR and Eastern Europe: Towards an Interwar Comparison}

In 1931 Stalin fixed the scale of the development lag between the USSR and the West: "We are fifty or a hundred years behind the advanced countries". ${ }^{1}$ These figures were chosen for effect, of course, not for their scholarly precision. For many purposes it would be good to put a more scientifically founded figure on the extent to which the interwar economies of the USSR and Eastern Europe lagged behind West European benchmarks. Such information is required for an analysis of the balance of economic forces on each side as Europe entered World War II, as much as for purposes of evaluating the subsequent performance of the East European economies under state socialism, once the immediate economic disruption of the war had been overcome.

How large were the gross domestic products of the Soviet and East European economies before World War II, and how high was GDP per head? To answer these questions, the national incomes of different countries must be converted to common accounting concepts and a common currency. Finding common concepts is, if anything, the easy part, since the differences between accounting systems East and West are well established. On the other hand the search for a common currency, revaluing rubles (say) in pounds or dollars, has to cross a terrain of notorious difficulty.

Such international comparisons are hard enough even in the present day. They become all the more awkward when the period to be reviewed is more than half a century removed, when the economies concerned lack good national income data, and when the largest of them was already being transformed structurally by violent processes under non-price controls quite different from those found in Western economies.

\section{GDP in a common currency}

\section{Purchasing power parities}

The core concept underlying most international comparisons of real output or income is purchasing power parity (PPP)-that rate of exchange between currencies which gives equal purchasing power over commodities. In principle PPPs can be defined for every good and service, as well as an average PPP for the economy as a whole. For example, in October 1993 a Big Mac was 1,800 rubles in Pushkin Square, and $£ 1.66$ in Britain, giving a PPP for Big Macs of nearly 1,100 rubles to $f 1$. We can divide total sales of Big Macs in Russia (in rubles) by this PPP to obtain sales in pounds sterling at purchasing power parity. Since sales of Big Macs in Russia and Britain are now measured in a common currency, we can go on to make a "real" comparison of sales volume in the two countries. The same exercise could be

\footnotetext{
${ }^{1}$ Stalin, Leninism, p. 366.
} 
repeated for sales of Stolichnaya vodka, then retailing at 2,500 rubles for a $35 \mathrm{cl}$ bottle in Moscow, but $£ 7.50$ in a British off-licence, yielding another PPP of only 330 or so rubles to $f 1$. (At the same time the free-market exchange rate was 1,800 rubles to $f 1$.) Repeated for every expenditure category, this procedure would yield each country's real national product in pounds sterling at purchasing power parity, together with an average PPP converter from rubles to pounds sterling for the whole economy, weighted by Russian quantities sold.

Alternatively we could reverse the process, converting British sales from pounds to rubles. For each good or service there would be a PPP converter, the reciprocal of the converter from rubles to pounds, and an average economy-wide converter weighted by British sales volumes.

The main problem is that the classifying and grading of output required by this ideal solution is hugely expensive. It requires years of work by teams of experts able to compare and evaluate the technological and quality standards of food and clothing products, machinery and vehicles, weapons, household appliances, buildings, transport services, medical, legal and financial services, and so on. Big Macs are easy-the whole point of a Big Mac is that it looks, tastes, and is the same everywhere in the world. The same can be said of few other commodities-not even bread, let alone more complex manufactures, and never mind services. Historians, lacking geopolitical justification for their bids to attract research funding on such a scale, face the added difficulty that the goods and services to be valued lie already in the distant past. Historical comparisons limited to the production industries are feasible, but coverage can be extended to the whole economy only with great difficulty. ${ }^{2}$

\section{PPPs and exchange rates}

Why not just use exchange rates? At least for market economies, one stratagem available to any traveller, journalist or historian is to use exchange rates to translate different countries' national products into a common currency; the alternatives to exchange rate conversion are so complicated that economists, too, sometimes use exchange rates.

Discussing the meaning of exchange rates may seem odd in a Soviet institutional context, where both domestic prices and the exchange rate were fixed arbitrarily, and a complex system of tariffs and levies closed the gap between prices in the home and foreign markets. Nonetheless, it must be considered here, because our aim is to measure Soviet GDP in terms comparable with the GDPs of market economies, where the relationship between exchange rates and PPPs assumes considerable importance.

${ }^{2}$ For a survey of recent research, see Crafts and Broadberry, "European productivity". 
Using exchange rates to convert GDPs to a common currency follows the spirit of the old "purchasing power parity" theory proposed by Gustav Cassel. ${ }^{3}$ This theory held that exchange rates tend to give different currencies equal purchasing power over goods and services. The theory, however, was flawed, being designed for a simple world of Big Mac-like homogeneous products, with competitive prices undistorted by transnational corporations and the regulation of commerce by government, and with no significant capital flows creating further demands for foreign currency unrelated to trade in commodities. In practice, exchange rates may be expected to diverge from purchasing power parity. Movements of capital, whether in the form of steady flows of long-term investment, or volatile speculative flows responding to interest rate differentials and expectations of future exchange rates, influence exchange rate alignments. The market power of companies over foreign markets and suppliers, and the commercial policy of governments with regard to tariffs and preferences, may also push exchange rate alignments away from purchasing power parity.

Worse still, even in the simple, ideal world of competitive markets under a laissez faire regime presupposed by the old "purchasing power parity" theory, exchange rates would tend to purchasing power parity only for those goods and services which are actually traded internationally. In practice, services are traded less than goods. It is generally thought that international productivity differences are less pronounced in service industries than in production industries. A lawyer, teacher or doctor in a low-income country will deliver something closer to the level of service in a high-income country than a worker in manufacturing or catering. But this is not reflected in the relative pay of lawyers, teachers and doctors in lowincome countries, since service sector wages there are held down by the low wages prevailing in the industries producing traded goods. ${ }^{4}$ As a result, relative GDP per head in the poorest countries may be understated by two or three times when measured using exchange rates, rather than PPP-based measures.

\section{Backward extrapolation from the present}

Historians lacking funds to reconstruct national accounts for the remote past at purchasing power parity, and wishing to avoid the pitfalls of exchange rate bias, can to some extent ride on the backs of present-day PPP-based comparisons. One method, exemplified by the recent work of Angus Maddison, estimates historical GDP relativities by extrapolating today's relativities back over past periods using estimated real GDP and population growth. ${ }^{5}$ This approach presumes good records of GDP and population over long periods. For the Soviet Union, Maddison combined

${ }^{3}$ For a critical review of the classical theory see Balassa, "The purchasing power parity doctrine".

${ }^{4}$ Kravis, "Comparative studies", pp. 28-29, Marer, Dollar GNPs, pp. 75-77. For a critical view see Lancieri, "Purchasing power parities", pp. 34-40.

${ }^{5}$ Maddison, Phases; Maddison, World Economy; Maddison, Dynamic Forces. An equivalent work of the Soviet period was IMEMO, "Sovetskii soyuz". 
Marer's study of Soviet and East European GDPs in 1980 (carried out for the World Bank) with independent Western estimates of Russian and Soviet economic growth since $1900 .{ }^{6}$ Marer's work was designed for comparability with Phase IV of the International Comparisons Project, and used the same "international" (purchasing power parity) dollars and 1980 prices. ${ }^{7}$ Subsequently the present author adjusted Maddison's figures in the light of later CIA figures for postwar GNP and a recent Soviet revision of interwar population, to obtain a best estimate of $\$ 1,826$ (in international dollars and 1980 prices) for Soviet GDP per head in 1938 , or about $50 \%$ of the United Kingdom. ${ }^{8}$

This $50 \%$ is on the high side by comparison with a previous estimate by Bairoch (39\% of the United Kingdom, shown in Table 1). However, Bairoch's lower figure should be considered inferior from the point of view of both sources and methods, being based on an earlier generation of Russian and Soviet national income and growth estimates, with Russian national income in 1913 calibrated by the 1913 ruble exchange rate and an arbitrary correction for exchange rate bias. ${ }^{9}$

Table 1. GDP relativities for the USSR and Eastern Europe, 1937-38

\begin{tabular}{|c|c|c|c|c|}
\hline & \multicolumn{2}{|c|}{$\begin{array}{c}\text { Bairoch, GNP per head in } \\
\text { 1938, scaled by US dollars } \\
\text { and prices of } 1960\end{array}$} & \multicolumn{2}{|c|}{$\begin{array}{l}\text { Ehrlich, GDP per head in } \\
1937, \text { scaled by current } \\
\text { prices and exchange rates }\end{array}$} \\
\hline & $\%$ of UK & Rank & $\%$ of UK & Rank \\
\hline USSR & 38.8 & 2 & 23.8 & 3 \\
\hline Bulgaria & 35.6 & 4 & 17.1 & 7 \\
\hline Czechoslovakia & 46.4 & 1 & 38.6 & 1 \\
\hline Hungary & 38.2 & 3 & 27.3 & 2 \\
\hline Poland & 31.5 & 5 & 22.7 & 4 \\
\hline Romania & 29.0 & 6 & 18.4 & 5 \\
\hline Yugoslavia & 28.7 & 7 & 18.1 & 6 \\
\hline
\end{tabular}

Sources: Calculated from Bairoch, "Europe's gross national product", p. 297; Ehrlich, "Contest between countries", p. 888 .

${ }^{6}$ Marer, Dollar GNPs, pp. 86-87. To extrapolate Soviet GDP and population back from 1980, Maddison used CIA, USSR: Measures of Growth and Development (subsequently updated in CIA, Measures of Soviet GNP) for Soviet GNP growth, 1950-80, and, for 1928-50, Moorsteen and Powell, Soviet Capital Stock.

${ }^{7}$ Results of ICP IV were reported in UN and EUROSTAT, World Comparisons.

${ }^{8}$ Harrison, "Russian and Soviet GDP", Table 2. Maddison, Dynamic Forces, p. 196 , opts to replace international dollars at 1980 prices by US dollars at prices of 1985; I retain the ICP IV concept in order to maintain comparability with Marer's Dollar GNPs. To convert percentages of the United Kingdom to percentages of the United States in international dollars and 1980 prices, divide by 1.27 for 1937, or 1.19 for 1938.

${ }^{9}$ Bairoch, "Europe's gross national product", p. 327. 
The figure of $\$ 1,826$ thus appeared to have respectable foundations; a variety of admittedly weak tests also failed to refute it. ${ }^{10}$ In the eyes of the present author, however, a main problem was that this figure necessarily lacked an anchor in contemporaneous comparisons. The World Bank study of Soviet GDP in 1980 had been criticized as itself erring on the high side, although it was by no means the highest of the available Western estimates. ${ }^{11}$ This was the major source of uncertainty; the Western CIA-derived growth estimates used for extrapolation back from 1980 were also under fire, but unofficial Soviet estimates did not refute them. ${ }^{12}$ It was clear that an estimate of interwar Soviet GDP per head anchored in contemporaneous evidence would be not just desirable, but superior to the unreliable product of a disputed 1980 base estimate of the Soviet GDP level, discounted by fragile estimates of more than 40 preceding years' Soviet economic growth.

${ }^{10}$ The tests are described in Harrison, "Russian and Soviet GDP", pp. 20-23. A contemporary Soviet estimate by Vasil'ev and Koval'son of TsSU, reported by Kudrov, istorii", p. 131, put Soviet "productivity of social labour" at $39 \%$ of the United States in 1937, i.e. perhaps half the United Kingdom, but this estimate does not inspire much credibility given the atmosphere of the time.

${ }^{11}$ Marer, Dollar GNPs, p. 86, found Soviet GNP per head in 1980 to be $\$ 5,550$ on a PPP basis (i.e. in international dollars of 1980 ), giving $47 \%$ as the ratio to the United States; this figure would have fallen to $44 \%$ by 1987 . In a lengthy survey of Western "exaggerations", Aslund, "How small is Soviet national income?", p. 43 approved Marer's study as "the best assessment of Soviet GNP, although it should be seen as a ceiling". Elsewhere, Aslund described Marer's work as "an improvement, but ... still likely to be too high". Aslund himself put the Soviet/US GNP per head relativity in 1986 at "barely 33\%". He also endorsed as "the best estimate to date" a supposedly alternative evaluation by Robert Campbell (again for the World Bank) of Soviet GNP per head in 1980 as only $37 \%$ of the US figure (ibid., pp. 38-39). In reality, however, there was no contradiction between Campbell and Marer. Campbell's was a study preparatory to Marer's, and estimated Soviet GNP both as if in exchange-rate dollars (the figure of $\$ 4,190$ cited by Aslund), as is the World Bank's normal practice, and at purchasing power parity $(\$ 5,613)$, on ICP IV lines (Campbell, "The conversion of national income data", Table 9; both these figures re-emerge in Marer, Dollar GNPs, p. 86). Taking into account exchange rate bias, Campbell's lower figure was to be expected. Other estimates, however, reviewed by Rosefielde, "Illusion of material progress", p. 606, and Kudrov, "Sovetskii Soyuz-SShA", were lower still.

${ }^{12}$ Thus estimates by Khanin, "Ekonomicheskii rost", p. 85, suggest that Soviet national income in 1980 had reached $427 \%$ of 1941, but this figure is barely distinguished from a figure of $438 \%$ of 1940 for Soviet GNP in 1980, derived by combining ClA estimates for 1950-80 with those of Moorsteen and Powell for 194050 (CIA, Measures of Soviet GNP, Table A-1; Moorsteen and Powell, Soviet Capital Stock, pp. 622-623). 


\section{Physical indicators}

\section{The method of physical indicators}

Returning to the prewar years to reprice the GDPs of the great powers directly was out of the question, but several compromise methods were available. In particular, in 1991 Eva Ehrlich of the Institute of World Economics, of the Hungarian Academy of Sciences, published the results of many years' research on international GDP relativities using the method of "physical indicators" (PIs), going back to $1937 .{ }^{13}$ By this method, Soviet 1937 GDP per head was estimated at $24 \%$ of the United Kingdom, not at purchasing power parity, but on an exchange rate scale, as if the USSR had had a market-valued GDP and currency on the same basis as other countries. This and other figures for Eastern Europe are shown in Table 1.

If $50 \%$ for the Soviet/UK relativity had seemed on the high side, $24 \%$ was very low. It seemed reasonable to suppose that eliminating exchange rate bias might raise Ehrlich's figure for the USSR, although by an unknown amount. ${ }^{14}$ The underlying reason for this expectation is that a true PPP scale would implicitly give greater weight to the services sector of the Soviet economy, where the productivity shortfall below West European standards may have been less than in production industries.

One possibility was therefore to replicate Ehrlich's work on 1937, but aiming for a PPP scale rather than one based on the market economies' exchange rates, and in all other respects using her sources and methods. The PI methodology has been reviewed elsewhere. ${ }^{15}$ However, a brief summary is necessary.

1. To begin with, figures for GDP per head are collected from countries with good national income data. GDPs are expressed in some common currency, either in exchange rate values or after repricing on the basis of purchasing power parities. Whichever is chosen will determine the units in which final results will be expressed.

2. Comparable data for Pls are collected from the countries with good and poor national income data alike. Those used for the interwar period include the per capita consumption of main types of food, consumer durables and industrial

${ }^{13}$ Ehrlich, Orszdgok versenye; the main findings are summarized in English in Ehrlich, "Contest between countries". The PI method was pioneered by the late Ferenc Janossy in the 1950s. Ehrlich participated in the early realization of his concepts; subsequently she developed and refined them, and extended their applications.

${ }^{14} 14$ According to Ehrlich, however, the extent of exchange rate bias was less between the wars than it would be today (personal communication).

${ }^{15}$ The PI methodology is available in English from Ehrlich as "The physical indicators (PI) method", an unpublished appendix to her "Contest between countries". Marer, Dollar GNPs, pp. 92-99, includes both an outline of the methodology, and an appraisal. Ehrlich has replied to her critics in "Contest between countries", pp. 876-877. 
materials, per capita stocks of transport equipment, and measures of informational activity (per capita stocks of radios and telephones, letters posted per head), as well as demographic indicators (rates of infant mortality). The main criterion for inclusion of a given $\mathrm{PI}$ is the strength of its relationship with observed GDP of the countries with good national income data.

3. The countries with good national income data form the population of a sample across which GDP per head may be regressed on the various PIs; each PI is taken one at a time as a single independent variable. Generally the logarithms of both dependent and independent variables are used. It is important to note that some regressions are determined graphically, by hand and eye, rather than by conventional least-squares techniques.

4. The regression lines now predict GDP per head for each country, with as many predicted (in Ehrlich's term "fictitious") GDPs as there are PIs and regressions.

5. For each country the geometric mean of these predicted GDPs now forms its "corrected" GDP.

6. In an iterative process, the regression and averaging procedure (steps 3 to 5 ) is repeated, substituting corrected for actual GDPs, until each corrected GDP has converged on its equilibrium value.

7. The final regression lines are now used to calculate the GDPs of countries with poor national income data which are predicted by each $\mathrm{PI}$, with the geometric mean of these values forming the final estimate of each country's GDP per head. An advantage of this procedure is its flexibility. Unlike a multiple regression approach, the researcher is not constrained by missing values or lack of degrees of freedom. The full range of available information can be used. However, there is a tendency to biased results; the corrected GDPs of the countries with good data may fail to coincide closely enough with observed GDPs, casting doubt on the predicted GDPs of countries with poor data. Ehrlich ascribes this to the difficulty of correctly specifying the functional form of the regression line in advance; this explains why a graphical procedure, plotting the regression line by hand and eye, is preferred to a conventional least-squares methodology. "Experience", she warns, "shows the graphical method is more flexible, [and] better adapts to the actual data. Up to now the functions determined by refined mathematical methods proved to be rigid and biased if contrasted to the graphical method". ${ }^{16}$

\section{Calibrating on a PPP scale}

For GDPs of the market economies at purchasing power parity I turned to the work of Maddison, which allowed calculation of GDPs per head within contemporary frontiers in 1937 (in some cases, 1938) for 24 countries shown in Table 2. For the physical indicators themselves, Ehrlich was kind enough to send me not only her detailed methodology but also her full data set and workings for $1937-65 .{ }^{17}$ These comprised some 26 physical indicators for 45 countries in 1937; there were many

\footnotetext{
${ }^{16}$ Ehrlich, "The physical indicators (PI) method", pp. 2-3.

${ }^{17}$ Ehrlich, "NemzetkOzi elemzesek".
} 
missing values, but coverage was fairly complete for the 24 countries with good national income data, and the seven countries of the USSR and Eastern Europe.

Table 2. Per capita GDPs of countries with good national income data for 1937 (international dollars at 1980 prices)

\begin{tabular}{|c|c|c|c|}
\hline Argentina $^{a}$ & 1898 & Italy & 1961 \\
\hline Australia & 3444 & Japan & 1333 \\
\hline Austria & 1807 & Mexico $^{a}$ & 847 \\
\hline Belgium & 2829 & Netherlands & 3221 \\
\hline Canada & 2935 & New Zealand ${ }^{a}$ & 4753 \\
\hline Chile $^{a}$ & 1847 & Norway & 2676 \\
\hline Denmark & 3254 & Portugal $^{a}$ & 916 \\
\hline Finland & 2114 & Sweden & 2692 \\
\hline France & 2586 & Switzerland & 3579 \\
\hline Germany & 2736 & Turkey $^{\mathrm{a}}$ & 1070 \\
\hline Greece $^{a}$ & 1373 & UK & 3610 \\
\hline Ireland $^{\mathrm{a}}$ & 1836 & USA & 4574 \\
\hline
\end{tabular}

Source: Calculated (except as noted below) from GDPs per head in 1980, and changes in GDP per head, 1937-80. Per capita GDPs for 1980 and in international dollars are taken from Maddison, World Economy, p. 112 (Table A-1). Changes in total GDP within present-day frontiers, 1937-80, from Maddison, Dynamic Forces, pp. 212-219 (Tables A-7, A-8), are adjusted to contemporary frontiers on the basis of notes to these tables; populations within contemporary frontiers in 1980 and 1937 are from Maddison, Dynamic Forces, pp. 232-239 (Tables B-3, B-4).

Note: ${ }^{a} 1938$, from per capita GDPs in 1980 , and changes in GDPs and populations, 1938-80, in Maddison, World Economy, appendices A, B, and C.

In my own approach to the PI methodology, I doubted that I had sufficient experience to replicate Ehrlich's graphical technique, and therefore I determined to calculate the regression lines mechanically using the least-squares method. Results of the first round of regressions are shown in Table $3 .^{18}$

Ehrlich warns that mechanical methods give biased estimates of corrected GDPs, but does not report the scale or direction of the bias. I found that the bias was substantial, and took the form of a strong tendency towards the mean. The GDPs of rich countries were underestimated and those of poor countries overestimated, the degree increasing with each round of the iterative process. Thus the coefficient of variation of the actual GDPs per head reported above in Table 2 is $42 \%$, but the coefficient of variation of corrected GDPs per head was only $28 \%$ after the first round, and fell further to $22 \%$ after the second.

${ }^{18}$ In the first round of the process, a set of single-variable regression equations of the form

$$
Y_{i}=\alpha_{0}+\alpha_{j} \cdot X_{i j}+u_{i}
$$

were estimated, where $Y_{i}$ is the logarithm of GDP per head of the ith country, $X_{i j}$ is the logarithm of the $j$ th physical indicator of the $i$ th country, $X_{i j}$ is the $j$ th $X$ coefficient to be estimated, and $u_{i}$ is a random disturbance. 
I tried to limit the bias by testing non-linear functional forms which would permit the regression line to bend where the data warranted it, but the extent of bias was virtually unaffected.

Table 3. Results of first-round regression of GDP per head against physical indicators, 1937

\begin{tabular}{|c|c|c|c|c|c|c|}
\hline $\begin{array}{l}\text { Independent } \\
\text { variable }\end{array}$ & Constant & $\begin{array}{r}\text { Standard } \\
\text { error of } \\
\text { estimate }\end{array}$ & $R^{2}$ & $N$ & $X$-coefficient & t-statistic \\
\hline STEELa ${ }^{a}$ & 5.9484 & 0.2528 & 0.7297 & 24 & 0.3981 & 7.7074 \\
\hline CEMENT & 5.0616 & 0.3072 & 0.6395 & 21 & 0.5909 & 5.8066 \\
\hline ELEC $^{a}$ & 6.1673 & 0.3053 & 0.5546 & 22 & 0.2670 & 4.9906 \\
\hline ENERGY $^{\mathrm{a}}$ & 4.9340 & 0.2606 & 0.7127 & 24 & 0.3888 & 7.3883 \\
\hline FUEL & 5.6526 & 0.2806 & 0.6669 & 24 & 0.3065 & 6.6370 \\
\hline ALUM & 7.9814 & 0.2518 & 0.0430 & 13 & 0.0661 & 0.7032 \\
\hline AG_WKR & 6.3433 & 0.3326 & 0.5616 & 18 & 0.6554 & 4.5279 \\
\hline FERT & 7.0687 & 0.3245 & 0.5096 & 21 & 0.1645 & 4.4439 \\
\hline TRACTOR & 7.3700 & 0.1849 & 0.8508 & 19 & 0.2535 & 9.8481 \\
\hline PROTEIN & 5.4927 & 0.2893 & 0.5812 & 23 & 0.6305 & 5.3987 \\
\hline SUGAR & 5.8619 & 0.3020 & 0.6141 & 24 & 0.5772 & 5.9177 \\
\hline COFFEE $^{a}$ & 7.3048 & 0.2497 & 0.6983 & 22 & 0.3758 & 6.8039 \\
\hline CEREAL & 15.3583 & 0.1812 & 0.7986 & 22 & -1.5836 & -8.9067 \\
\hline MILK & 6.3945 & 0.3176 & 0.3993 & 21 & 0.2621 & 3.5539 \\
\hline TEXTILE $^{\mathrm{a}}$ & 5.9845 & 0.2907 & 0.6426 & 24 & 0.9431 & 6.2905 \\
\hline RLWY_TON & 5.3637 & 0.2757 & 0.6847 & 23 & 0.3059 & 6.7534 \\
\hline RLWY_TKM ${ }^{a}$ & 6.1452 & 0.3791 & 0.3922 & 24 & 0.2603 & 3.7683 \\
\hline ROAD_VEH & 6.9031 & 0.2614 & 0.7109 & 24 & 0.2819 & 7.3565 \\
\hline PASS_CAR ${ }^{a}$ & 7.1227 & 0.2948 & 0.6487 & 23 & 0.2370 & 6.2279 \\
\hline HGV_PSV & 7.2245 & 0.2139 & 0.7813 & 22 & 0.3194 & 8.4552 \\
\hline W_PAPER & 6.8242 & 0.2383 & 0.7098 & 18 & 0.3158 & 6.2568 \\
\hline NEWSPRNT ${ }^{\mathrm{a}}$ & 7.0441 & 0.2552 & 0.7245 & 24 & 0.3755 & 7.6075 \\
\hline $\mathrm{TEL}^{\mathrm{a}}$ & 6.2527 & 0.2159 & 0.7879 & 23 & 0.4051 & 8.8345 \\
\hline RADIO $^{a}$ & 6.5587 & 0.2849 & 0.6567 & 24 & 0.2863 & 6.4882 \\
\hline INF_MORT ${ }^{\mathrm{a}}$ & 10.8317 & 0.2934 & 0.6086 & 23 & -0.7173 & -5.7145 \\
\hline LETTERSS $^{a}$ & 6.1095 & 0.2631 & 0.6905 & 21 & 0.3936 & 6.5120 \\
\hline
\end{tabular}

Sources: For the dependent variable (GDP per head in international dollars at 1980 prices), see Table 2 . Sources and definitions of independent variables are given in the data appendix. All variables are expressed in natural logarithms.

Note: ${ }^{a}$ These variables were retained for estimating the regression models in Tables 4 and 5.

Sources of bias in the PI method

This led me to conclude that the bias is a result not of misspecification of the functional form, as Ehrlich maintains, but of missing variables. Each PI regression is a highly imperfect model which predicts GDP relatively poorly (Table 3 showed that the typical $R^{2}$ is in the region of 0.7 ), because each model is limited to one independent variable, so that many significant variables are always omitted. Averaging the individual results of a set of poor individual predictors increases the extent of bias. 
The bias expresses the fact that regression techniques are being used under conditions to which they are not well suited; for example, since corrected GDP is the geometric mean of many predictions, each independent variable is forced to bear equal weight and significance, rather than its weight and significance being decided by the data. This should not rule out the PI methodology in itself, since the terrain of endeavour is pretty rough, and the main test of a technique is whether or not it helps us across. However, the PI methodology can only work as a result of arbitrary manipulations of each PI regression to increase its slope.

I decided that this method should be left to the skill of the experienced practitioner. On the other hand, I was still in possession of a considerable volume of comparable PI data for countries with and without good national income data, compiled as a result of great labour over many years by Ehrlich and her colleagues.

\section{Multiple regression}

\section{Data and method}

An obvious recourse was therefore to a second main tradition of indirect estimation of development levels based on physical indicators, which relies on multiple regression techniques; the main postwar exponents of this approach have been Francis Seton, Wilfrid Beckerman and Nick Crafts. ${ }^{19}$

The core principle is the same as for the PI methodology. Per capita GDPs of economies with good national income data are regressed on physical indicators (independent variables), in order to generate a predictive model which can then be applied to countries with poor national income data. ${ }^{20}$ As in the PI methodology, GDPs must be expressed in some common currency, either in exchange rate values or after repricing on the basis of purchasing power parities. Whichever is chosen will determine the units in which final results will be expressed. For the dependent variable I use the GDPs reported in Table 2, which are measured in PPP-based international dollars at 1980 prices, so the "predicted" interwar GDPs of the USSR and Eastern Europe are measured in the same currency. All variables are transformed into logarithms, so that the X-coefficients can be interpreted as elasticities.

The main difference from the PI methodology is that the data, not the observer, decide the significance and weights to be attached to the independent variables. Once the data have been collected, the role of the observer is limited to setting criteria for the order of elimination of insignificant variables from the predictive

${ }^{19}$ Seton, "Tempo of Soviet industrial expansion"; Seton, "Soviet progress"; Beckerman and Bacon, "International comparisons"; Crafts, "Gross national product".

${ }^{20}$ For comparison with the PI methodology (see note 18 for definition of symbols used), a multiple regression approach with $j$ physical indicators involves estimating the X-coefficients in a single-equation model of the form

$$
Y_{i}=\alpha_{0}+\alpha_{1} \cdot X_{i 1}+\alpha_{2} \cdot X_{i 2}+\alpha_{j} \cdot X_{i j}+u_{i}
$$


model. The main disadvantage of multiple regression is that its data requirements are more rigid.

Adapting Ehrlich's data set to a multiple regression approach was mainly a matter of deciding what to do about physical indicators (independent variables) with missing values. I was able to fill in a few gaps, and I also created two new variables, surface area per head (to allow for the income-generating influence of a rich resource endowment) and population (in order to pick up any effects arising from economies of scale). But I had to leave out all variables for which the USSR did not report a value, since I was not interested in a model which could not estimate Soviet GDP; unfortunately, this meant losing the majority of food-related variables.

At the end, I retained 15 independent variables, including the two new ones, and a few with missing values for Turkey, Mexico or Chile. I wanted to keep as many middle to low-income countries in the sample as possible, since I expected the USSR and Eastern Europe to belong to this end of the spectrum; I was also reluctant to lose a number of variables which looked relatively powerful as individual GDP predictors (in Table 3), just because of one or two missing values, so I created new dummy variables, for each country with missing values, in order to allow an estimate of the influence of the values which were missing.

To begin with, estimation proceeded simply by throwing in all remaining variables in order to see how they performed in practice. I eliminated variables from the regression model one at a time, starting with the least significant, until all the $\mathrm{X}$ coefficients were significant at the $5 \%$ level. Sometimes, when a variable with one or more missing values was eliminated, a dummy variable associated with the missing value could be eliminated at the same time, and in practice no country dummy remained in the competition until the end.

Results

Some common patterns emerged from the search for significance. Surface area per head invariably dropped out sooner or later, suggesting that it carried penalties of remoteness as well as advantages of resource endowment. Also against expectation, ton-kilometres of railway freight performed badly and dropped out at the same stage, perhaps for the same reason, whereas crude freight tonnage performed consistently well. The population variable failed to show any evidence of economies of scale, and invariably dropped out at an intermediate stage.

Another pattern was the poor performance of consumption of such basic industrial products as steel, electricity and textiles. In practice these were usually poor predictors of GDP per head. Much more powerful were indicators connected with transport, communications and information facilities-railway tonnage, stocks of motor vehicles and telephones, newsprint consumed, domestic letters posted. Infant mortality, too, usually held up well as a GDP predictor.

It soon became clear, however, that, with at most 24 observations, no very powerful model would emerge from the data available. I could find no strong evidence that extreme observations were getting in the way of firm results; it was simply that the sample was small, making the standard error of the GDP estimate typically large. In the end, I approached the data from three different starting points. 
The models emerging from these three routes are shown in Table 4, with results summarized in Table 5.

Table 4. Four models for predicting GDP per head (in international dollars at 1980 prices) of countries with poor national income data, 1937

\begin{tabular}{|c|c|c|c|c|}
\hline & \multirow[t]{2}{*}{ (A) } & \multirow[t]{2}{*}{ (B) } & \multicolumn{2}{|l|}{ (C) } \\
\hline & & & Version 1 & Version 2 \\
\hline \multicolumn{5}{|l|}{ Regression output } \\
\hline Standard error of estimate & 0.1804 & 0.1411 & 0.2229 & 0.2215 \\
\hline$R^{2}$ & 0.8810 & 0.9021 & 0.7994 & 0.8112 \\
\hline Number of observations & 24 & 21 & 24 & 24 \\
\hline Degrees of freedom & 19 & 17 & 21 & 20 \\
\hline $\begin{array}{l}\text { F of regression } \\
\text { Independent variables }\end{array}$ & \multicolumn{3}{|c|}{ Independent variables } & 28.6566 \\
\hline \multicolumn{5}{|l|}{ CONST } \\
\hline X-coefficient & 6.5938 & 8.5699 & 6.3647 & 5.8224 \\
\hline Standard error & 0.3116 & 0.5779 & 0.2588 & 0.3173 \\
\hline$t$-statistic & 21.156 & 14.8273 & 24.5849 & 18.3479 \\
\hline \multicolumn{5}{|l|}{ STEEL } \\
\hline X-coefficient & $\ldots$ & $\ldots$ & 0.2233 & 0.1920 \\
\hline Standard error & $\ldots$ & $\ldots$ & 0.0794 & 0.0858 \\
\hline$t$-statistic & $\ldots$ & $\ldots$ & 2.8002 & 2.2377 \\
\hline \multicolumn{5}{|l|}{ RLWY_TON } \\
\hline X-coefficient & 0.1005 & 0.1288 & $\ldots$ & 0.1118 \\
\hline Standard error & 0.0506 & 0.0336 & $\ldots$ & 0.0636 \\
\hline$t$-statistic & 1.9843 & 3.8299 & $\ldots$ & 1.7585 \\
\hline \multicolumn{5}{|l|}{ PASS_CAR } \\
\hline X-coefficient & 0.0663 & 0.0752 & $\ldots$ & 0.0779 \\
\hline Standard error & 0.0328 & 0.0248 & $\ldots$ & 0.0376 \\
\hline$t$-statistic & 2.0194 & 3.0283 & $\ldots$ & 2.0693 \\
\hline \multicolumn{5}{|l|}{ NEWSPRNT } \\
\hline X-coefficient & ... & $\ldots$ & 0.2031 & $\ldots$ \\
\hline Standard error & $\ldots$ & $\ldots$ & 0.0751 & $\ldots$ \\
\hline$t$-statistic & $\ldots$ & $\ldots$ & 2.7017 & $\ldots$ \\
\hline \multicolumn{5}{|l|}{ TEL } \\
\hline X-coefficient & 0.2040 & $\ldots$ & $\ldots$ & $\ldots$ \\
\hline Standard error & 0.0613 & $\ldots$ & $\ldots$ & $\ldots$ \\
\hline$t$-statistic & 3.3240 & $\ldots$ & $\ldots$ & $\ldots$ \\
\hline \multicolumn{5}{|l|}{ INFMORT } \\
\hline X-coefficient & -0.1280 & -0.4678 & $\ldots$ & $\ldots$ \\
\hline Standard error & 0.0387 & 0.0974 & $\ldots$ & $\ldots$ \\
\hline$t$-statistic & -3.2997 & -4.7990 & $\ldots$ & $\ldots$ \\
\hline
\end{tabular}

Key: (A) Full data set (24 countries, 18 independent variables including 3 country dummies). Sources and definitions of independent variables are given in the data appendix. All variables are expressed in natural logarithms. (B) No observations with missing values (21 countries, 15 independent variables). (C) No variables with missing values (24 countries, 11 independent variables). Sources: As Table 3. 
Table 5. Estimated GDP per head of the USSR and Eastern Europe, 1937 (international dollars and 1980 prices)

\begin{tabular}{|c|c|c|c|c|c|}
\hline & \multirow[b]{2}{*}{ GDP per head } & \multirow[b]{2}{*}{ Rank } & \multirow[b]{2}{*}{$\%$ of UK } & \multicolumn{2}{|c|}{ 95\% confidence intervals } \\
\hline & & & & lower & upper \\
\hline \multicolumn{6}{|c|}{ (A) Full data set } \\
\hline USSR & 1,157 & 4 & 32 & 807 & 1,660 \\
\hline Bulgaria & 936 & 7 & 26 & 652 & 1,342 \\
\hline Czechoslovakia & 1,841 & 1 & 51 & 1,283 & 2,642 \\
\hline Hungary & 1,638 & 2 & 45 & 1,142 & 2,350 \\
\hline Poland & 1,241 & 3 & 34 & 865 & 1,781 \\
\hline Romania & 1,095 & 5 & 30 & 763 & 1,571 \\
\hline Yugoslavia & 1,013 & 6 & 28 & 706 & 1,453 \\
\hline \multicolumn{6}{|c|}{ (B) No observations with missing values } \\
\hline USSR & 1,303 & 4 & 36 & 983 & 1,729 \\
\hline Bulgaria & 1,148 & 7 & 32 & 866 & 1,522 \\
\hline Czechoslovakia & 1,948 & 1 & 54 & 1,469 & 2,584 \\
\hline Hungary & 1,599 & 2 & 44 & 1,206 & 2,121 \\
\hline Poland & 1,372 & 3 & 38 & 1,035 & 1,820 \\
\hline Romania & 1,237 & 6 & 34 & 932 & 1,640 \\
\hline Yugoslavia & 1,275 & 5 & 35 & 961 & 1,691 \\
\hline \multicolumn{6}{|c|}{ (C) No variables with missing values } \\
\hline \multicolumn{6}{|l|}{ Version 1: } \\
\hline USSR & 1,698 & 2 & 47 & 1,087 & 2,652 \\
\hline Bulgaria & 1,158 & 6 & 32 & 742 & 1,809 \\
\hline Czechoslovakia & 1,935 & 1 & 54 & 1,239 & 3,022 \\
\hline Hungary & 1,660 & 3 & 46 & 1,063 & 2,592 \\
\hline Poland & 1,214 & 4 & 34 & 778 & 1,897 \\
\hline Romania & 1,190 & 5 & 33 & 762 & 1,859 \\
\hline Yugoslavia & 1,117 & 7 & 31 & 715 & 1,744 \\
\hline \multicolumn{6}{|l|}{ Version 2: } \\
\hline USSR & 1,964 & 2 & 54 & 1,261 & 3,059 \\
\hline Bulgaria & 1,296 & 6 & 36 & 832 & 2,018 \\
\hline Czechoslovakia & 2,443 & 1 & 68 & 1,569 & 3,806 \\
\hline Hungary & 1,880 & 3 & 52 & 1,207 & 2,929 \\
\hline Poland & 1,477 & 5 & 41 & 948 & 2,301 \\
\hline Romania & 1,493 & 4 & 41 & 959 & 2,326 \\
\hline Yugoslavia & 1,266 & 7 & 35 & 812 & 1,971 \\
\hline
\end{tabular}

Source: As Table 4.

Model (A). This model was estimated starting from the fullest possible data set, including some observations (countries) and variables (indicators) with missing values, and three country dummies (Turkey, Mexico and Chile). The full data set supported a model in which significant contributions to explaining GDP relativities were provided by railway freight tonnage, the stocks of passenger cars and telephones, and the state of infant mortality.

Two other models emerged after dispensing with country dummies, in the case of model (B) eliminating observations with missing values, and in the case of model (C) by eliminating variables with missing values. 
Model (B). Restricting the data set by excluding the three countries with missing values resulted in a model with one less variable (telephones per head), but the remaining variables were each more powerful, generating higher individual t-values, with a smaller standard error of the GDP estimate and a higher value of $F$ for the regression as a whole. I came to think of this as the most robust of the models tested, although not the only one with something to tell us.

Model (C). In the third case, indicator variables with missing observations were omitted; this was the only model in which the consumption of traditional industrial materials such as steel played a role. The selection of other variables involved fine choices, and eventually two possible models emerged from this data set. In the first (version 1), only the consumption of steel and newsprint shared significant explanatory power, and the resulting standard error of the GDP estimate was relatively large. In the second (version 2), newsprint consumption was replaced by railway tonnage and the stock of passenger cars; all the variables were only weakly significant, and the standard error of the estimates was larger still.

The results predicted by these four models are shown in Table 5 . The first column shows estimated GDP per head in international (PPP) dollars and 1980 prices, and the second shows the rank order. The third column shows estimated GDP per head as a percentage of the United Kingdom. The fourth and fifth show 95\% confidence limits of the GDP estimate. Soviet GDP per head is shown at anything from $32 \%$ to $54 \%$ of United Kingdom GDP per head, but these estimates themselves have a wide error margin; the lower limit of the lowest estimate is under $\$ 1,000$, while the upper limit of the highest is over $\$ 3,000$, compared with $\$ 3,610$ as GDP per head of the United Kingdom.

Although there is a lot of uncertainty here, it is possible to discriminate between the different models. Model (B) appears to be the most robust. Therefore, the strongest signals of contemporaneous data support a best estimate for Soviet GDP per head in 1937 in the region of $40 \%$ of the United Kingdom or less; the figure of $50 \%$ which emerges by extrapolation backward from near the present day, while not ruled out, receives much weaker backing.

As may be expected, the alternative models also yield differences as well as common features in ranking the economies of the East European region by GDP per head. Czechoslovakia emerges consistently as the most developed of the East European economies, but by a varying margin. Bulgaria, Poland, Romania and Yugoslavia are generally found close together at the bottom of the heap. In models (A) and (B), which stress transport and communications indicators, Hungary is ranked second, while the USSR is numbered among the low-income countries of the region. In model (C), the weight attached to steel consumption raises the USSR to second place and pushes Hungary down.

These findings can be compared with the previous results of Bairoch and Ehrlich (Table 1). Models (A) and (B) produced a rank order for the East European countries close to that obtained by Ehrlich using the Hungarian PI methodology and an exchange rate scale. Of course, all the percentages of the United Kingdom are higher than she found-the expected result of replacing an exchange rate scale with purchasing power parities. 
Placing Soviet GDP per head at around 40\% of the United Kingdom in 1937 neatly matches Bairoch's figure of $39 \%$ for 1938 , but by accident, since Bairoch's procedure cannot be judged reliable. None of the models developed here produced any confirmation of Bairoch's ranking.

\section{Conclusions}

The contemporaneous data available do not lend strong support to any hard and fast estimates for real per capita GDPs of the USSR and Eastern Europe in the 1930s. They give out a variety of weak, confused signals, and are consistent with a wide range of estimates of interwar GDP relativities. Not only do alternative models show Soviet GDP per head in 1937 at anything from 32\% to 54\% of the United Kingdom, but these estimates are themselves subject to large error margins.

Nonetheless, it is clear that $50 \%$ of the United Kingdom, the figure which results from extrapolation backward from near the present day, is at the top of the range of what is likely. Safer ground would be offered by an estimate for 1937 of not more than $40 \%$ of the United Kingdom, say, $\$ 1,440$ in international dollars at 1980 prices.

As far as the USSR is concerned, the choice of indicators for inclusion in the predictive model is very sensitive. There are two reasons for this. One is the sample size, which is too small to allow more than three or four significant independent variables to emerge; the latter are too few reliably to explain interwar GDP relativities. A second reason is the Soviet economic structure, which diverged markedly from the norm found among countries with good national income data. ${ }^{21}$ Thus, indicators stressing the use of industrial materials like steel or electricity give much higher estimates of the Soviet development level than those reflecting the development of communications and information services.

There may be an historical irony here. When Lenin and Stalin looked to the west, they identified steel, cement and electric power as the keys to catching up with the West in per capita product terms. Yet these turn out to have been relatively poor predictors of the development level of the Western economies at the time. Already more important, arguably, were the new technologies of motor transport, communications and information.

Does this mean that lower priority for steel, and more emphasis on transport and telecommunications, would have accelerated Soviet economic development? Not automatically, since we have not shown any causal links, only statistical associations. It may also be argued that the Soviet economy found its own development path, the achievements of which are undervalued by international dollars at 1980 prices.

However, the possibility remains that a part was played by Soviet misconceptions of the roots of Western economic progress. This applied to material prosperity and military power alike. One can almost hear the rejoinder of a Molotov: "when it came to war, we needed armour steel, not information technology; you

\footnotetext{
${ }^{21}$ In other words, the use of single indicators such as electricity consumption to gauge US-Soviet GDP relativities is not advisable (e.g. Kudrov, "Iz istorii", p. 142).
} 
can't kill a German with a telephone receiver". Yet, once World War II broke out, the Red Army found itself critically deficient in field telecommunications, and eventually imported more than a million miles of telephone cable from the United States under Lend-Lease. $^{22}$

If we take GDP per head of $\$ 1,440$ as a rough measure of the Soviet development level on the eve of World War II, then this level had previously been achieved by France and Germany in the 1890s, and by the United States and the United Kingdom around the middle of the 19th century. ${ }^{23}$ Thus, Stalin's famous aphorism of 1931 ("We are fifty or a hundred years behind the advanced countries") appears to have been quite accurate, and still largely applicable to the relative position of the Soviet economy in 1937, even after two five-year plans.

\section{References}

Aslund, A., "How small is Soviet national income?", in H.S. Rowen and C. Wolf eds, The Impoverished Superpower: Perestroika and the Soviet military burden (San Francisco, CA, 1990), pp. 13-62.

Bairoch, P., "Europe's gross national product: 1800-1975", Journal of European Economic History, 5, 1976, pp. 273-340.

Balassa, B., "The purchasing power parity doctrine: a reappraisal", Journal of Political Economy, 72, 1964, pp. 584-596.

Beckerman, W., and R. Bacon, "International comparisons of income levels: a suggested new measure", Economic Journal, 76, 1966, pp. 519-536.

Central Intelligence Agency, Measures of Soviet Gross National Product in 1982 Prices (Washington, DC, 1990).

Central Intelligence Agency, USSR: Measures of Economic Growth and Development, 1950-1980 (Washington, DC, 1982).

Crafts, N. F. R., "Gross national product in Europe, 1870-1910: some new estimates", Explorations in Economic History, 20, 1983, pp. 387-401.

Crafts, N. F. R., and S. N. Broadberry, "European productivity in the twentieth century: introduction", Oxford Bulletin of Economics and Statistics, 52, 1990, pp. 331-341.

Ehrlich, E., "Nemzetlchzi elemzesek a magyar tavlati tervezeshez", Orszdgos Tervhivatal Tervgaz-dasdgi Intezet, 2, 1968, pp. 1-175.

Ehrlich, E., Orszdgok versenye 1937-1986 (Budapest, 1991).

Ehrlich, E., "Contest between countries: 1937-1986", Soviet Studies, 43, 5, 1991, pp. 875-896.

Ehrlich, E., "The physical indicators (PI) method", unpublished appendix to "Contest between countries" (Budapest, 1991).

\footnotetext{
22 Jones, Roads to Russia, Appendix A, Table 5.

${ }^{23}$ This relies on interpolation from Maddison's estimates of GDP and population given across isolated benchmarks in the 19th century for a small sample of countries. See Maddison, World Economy, Appendices A, B, C.
} 
Harrison, M., "Russian and Soviet GDP on the eve of two World Wars: 1913 and 1940", Soviet Industrialisation Project Series, no. 33 (University of Birmingham, 1992).

Institut mirovoi ekonomiki i mezhdunarodnykh otnoshenii (IMEMO), "Sovetskii soyuz v mirovoi ekonomiki (1917-1987 gg.)", Mirovaya ekonomika i mezhdunarodnye otnoshenii, 11, 1987, pp. 145-157.

Jones, R. H., Roads to Russia: United States Lend-lease to the Soviet Union (Norman, OK, 1969).

Khanin, G. I., , "Ekonomicheskii rost: al'ternativnaya otsenka”, Kommunist, 17, 1988, pp. 83-90.

Kudrov, V. M., "Sovetskii Soyuz-SShA: k sravneniyu ekonomicheskoi moshchi", Svobodnaya mysl', 17, 1991, pp. 88-96.

Kudrov, V. M., "Iz istorii i praktiki sopostavleniya ekonomicheskoi moshchi SSSR i SShA", Izv. AN SSSR Ser. ekon., 6, 1991, pp. 131-144.

Maddison, A., Phases of Capitalist Development (Oxford, 1982)

Maddison, A., The World Economy in the 20th Century (OECD, Paris, 1989).

Maddison, A., Dynamic Forces in Capitalist Development: A long-run comparative view (Oxford, 1991).

Marer, P., Dollar GNPs of the USSR and Eastern Europe London, 1985).

Mitchell, B. R., European Historical Statistics, 1750-1970 (London, 1975).

Mitchell, B. R., International Historical Statistics: The Americas and Australasia (London, 1983).

Moorsteen, R., and R. P. Powell, The Soviet Capital Stock, 1928-1962 (Homewood, IL, 1966).

Rosefielde, S., "The illusion of material progress: the analytics of Soviet economic growth revisited", Soviet Studies, 43, 4, 1991, pp. 597-611.

Seton, F., "The tempo of Soviet industrial expansion", Manchester Statistical Society, 2, 1956-57, pp. 1-39.

Seton, F., "Soviet progress in western perspective", Soviet Studies, 12, 2, 1960, pp. 126-144. Statistical yearbook of the League of Nations, 1937/38 (Geneva, 1938).

United Nations and EUROSTAT, World Comparison of Purchasing Power and Real Product for 1980, 2 vols (New York, 1986). 
Data appendix

Table A-1. Sources and definitions of independent variables

\begin{tabular}{|c|c|c|c|c|}
\hline \multirow[b]{3}{*}{ Variable } & \multirow[b]{3}{*}{ Definition } & \multirow[b]{3}{*}{ Unit } & \multicolumn{2}{|c|}{ Missing values } \\
\hline & & & of 24 countries with & of 7 countries with \\
\hline & & & good GDP data & poor GDP data \\
\hline POP & Population $^{a}$ & $1,000 s$ & 0 & 0 \\
\hline AREA & Surface area of territory ${ }^{b}$ & $\mathrm{~km}^{2} /$ head & 0 & 0 \\
\hline STEEL & Steel consumed & $\mathrm{kg} / \mathrm{head}$ & 0 & 0 \\
\hline CEMENT & Cement consumed $^{c}$ & $\mathrm{~kg} / \mathrm{head}$ & 3 & 0 \\
\hline ELEC & Electricity consumed $^{d}$ & kWh/head & 1 & 0 \\
\hline ENERGY & Energy consumed from all sources, fuel equivalents & $\mathrm{kg} / \mathrm{head}$ & 0 & 0 \\
\hline FUEL & Solid fuel consumed & $\mathrm{kg} / \mathrm{head}$ & 0 & 1 \\
\hline ALUM & Aluminium consumed & $\mathrm{kg} / \mathrm{head}$ & 11 & 7 \\
\hline AG_WKR & Numbers fed by one agricultural worker & persons & 6 & 3 \\
\hline FERT & Mineral fertilizer consumed & $\begin{array}{l}\mathrm{kg} / 1,000 \text { agri- } \\
\text { cultural workers }\end{array}$ & 3 & 2 \\
\hline TRACTOR & Tractors in use ${ }^{e}$ & $\begin{array}{l}\text { units } / 1,000 \text { agri- } \\
\text { cultural workers }\end{array}$ & 5 & 0 \\
\hline PROTEIN & Animal proteins consumed & gms/head/day & 1 & 3 \\
\hline SUGAR & Sugar consumed ${ }^{f}$ & $\mathrm{~kg} / \mathrm{head}$ & 0 & 2 \\
\hline COFFEE & Coffee, cocoa and tea consumed & $\mathrm{kg} / \mathrm{head}$ & 2 & 1 \\
\hline CEREAL & Cereals (including flour) consumed ${ }^{g}$ & $\mathrm{~kg} / \mathrm{head}$ & 2 & 4 \\
\hline MILK & Milk and dairy products consumed & kcals/head & 3 & 7 \\
\hline TEXTILE & Textile fibres consumed & $\mathrm{kg} / \mathrm{head}$ & 0 & 0 \\
\hline RLWY TON & Railway freight ${ }^{\text {h }}$ & $\mathrm{kg} / \mathrm{head}$ & 0 & 0 \\
\hline RLWY TKM & Railway freight ${ }^{i}$ & ton-km /head & 0 & 0 \\
\hline ROAD VEH & Road vehicles registered & units $/ 1,000$ & 0 & 1 \\
\hline PASS_CAR & Passenger cars registered ${ }^{j}$ & units $/ 1,000$ & 0 & 0 \\
\hline HGV_PSV & Heavy goods and public service vehicles registered & units $/ 1,000$ & 1 & 1 \\
\hline WPAPER & Wrapping paper consumed & $\mathrm{kg} / \mathrm{head}$ & 6 & 0 \\
\hline NEWSPRNT & Newsprint consumed & $\mathrm{kg} / \mathrm{head}$ & 0 & 0 \\
\hline
\end{tabular}




\begin{tabular}{|c|c|c|c|c|}
\hline \multirow[b]{2}{*}{ Variable } & \multirow[b]{2}{*}{ Definition } & \multirow[b]{2}{*}{ Unit } & \multicolumn{2}{|c|}{ Missing values } \\
\hline & & & $\begin{array}{l}\text { of } 24 \text { countries with } \\
\text { good GDP data }\end{array}$ & $\begin{array}{c}\text { of } 7 \text { countries with } \\
\text { poor GDP data }\end{array}$ \\
\hline TEL & Telephones in use $\mathrm{k}^{\mathrm{k}}$ & units $/ 1,000$ & 1 & 0 \\
\hline INF_MORT & Infant mortality (under one year) & deaths $/ 1,000$ & 1 & 0 \\
\hline LETTERS & Domestic letters posted $^{\mathrm{m}}$ & units/head & 0 & 0 \\
\hline
\end{tabular}

Source: Ehrlich, “Nemzetkrizi elemzesek”, pp. 8-24, except as noted below.

Notes:

a. All figures as Table 2 (above).

b. All figures from Statistical Yearbook, pp. 16-23.

c. Hungary, Yugoslavia, 1938.

d. Finland from Mitchell, European Historical Statistics, p. 481.

e. Austria, Denmark, Germany, Greece, Italy, Ireland, Netherlands, Norway, Portugal, United Kingdom, 1934-38 average. Bulgaria, Czechoslovakia, Finland, France, Japan (including garden tractors), New Zealand, Poland, Sweden, Turkey, Yugoslavia, 1939.

f. Poland, 1933-37 average. Greece, Germany, Mexico, Argentina, Chile, 1935-38 average. Czechoslovakia, 1936. Netherlands, Australia, 1936-38 average. Hungary, 1938.

g. Hungary, 1934-38 average. Czechoslovakia, 1936. Poland, 1938.

h. Germany, 1936. France, Italy (excluding livestock), Romania 1938. Bulgaria, 1939. USSR, 1940. Czechoslovakia, excludes Carpathian Ukraine. Denmark from Mitchell, European Historical Statistics, p. 595. Hungary excludes state railways.

i. Czechoslovakia, 1936. Romania 1938. Bulgaria, 1939. Austria, France, Italy, state railways only. Chile, gross ton-km. Hungary excludes state railways. Ireland two main lines only. Poland excludes narrow-gauge railways. Turkey excludes livestock. United Kingdom excludes Northern Ireland. Finland from Mitchell, European Historical Statistics, p. 639.

j. Austria, 1936. USSR, 1935.

k. Argentina, Czechoslovakia, Poland, Romania, 1938, USSR, 1940.

I. Austria, 1936. Chile from Mitchell, International Historical Statistics, p. 741. Italy, Portugal from Mitchell, European Historical Statistics, pp. 660-1. 